\title{
Associations between substandard housing and depression: insights from the Korea welfare panel study
}

\author{
Selin Kim ${ }^{1,2}$, Wonjeong Jeong ${ }^{1,2}$, Bich Na Jang ${ }^{1,2}$, Eun-Cheol Park ${ }^{2,3}$ and Sung-In Jang ${ }^{2,3^{*}}$ (D
}

\begin{abstract}
Background: Housing is an important social determinant of health. Poor housing conditions are associated with a wide range of health conditions, including mental health. The study aimed to investigate the association between substandard housing and depression.

Methods: We used panel data collected by the Korea Welfare Panel Study and a sample drawn from waves 11 (2016) to 13 (2018). Substandard housing was defined via three criteria: the minimum residential area and number of rooms by application, essential facility standards, and environmental standards. Depression was measured with the CESD-11. A generalized estimating equation model was used to investigate associations between substandard housing and CESD-11 scores.

Results: Participants living in substandard housing have higher depression scores (male: $\beta=0.63$, female: $\beta=0.40$ ) than participants who do not live in substandard housing. Participants who do not meet environmental standards have higher depression scores (male: $\beta=0.85$, female: $\beta=0.66$ ) than participants who do not live in substandard housing; the findings are seen in both men and women.

Conclusion: This study identified an association between substandard housing and depression by gender, and the results were significant. We found that among the three criteria, environmental standards are most likely to be associated with depression. In practical terms, we should consider improving environmental factors of housing to mitigate mental health issues related to substandard housing.
\end{abstract}

Keywords: Minimum housing standard, Substandard housing, Depression

\section{Background}

The human right to adequate housing, which is derived from the right to an adequate standard of living, is of central importance for the enjoyment of all economic, social, and cultural rights [1]. Acknowledging this truth, in 1991, the UN committee on Economic, Social, and

\footnotetext{
* Correspondence: JANGSI@yuhs.ac

${ }^{2}$ Institute of Health Services Research, Yonsei University, Seoul, Republic of Korea

${ }^{3}$ Department of Preventive Medicine \& Institute of Health Services Research, Yonsei University College of Medicine, 50 Yonsei-ro, Seodaemun-gu, Seoul 03722, Republic of Korea

Full list of author information is available at the end of the article
}

Culture Rights announced seven elements of adequate housing (legal security of tenure; availability of services, materials, facilities, and infrastructure; affordability; habitability; accessibility; location; and cultural adequacy) [2]. The committee emphasized that the right to housing should not be interpreted in a narrow or restrictive sense; rather, it should be seen as the inalienable right to live somewhere in security, peace, and dignity.

The Republic of Korea has established minimum housing standards and has been actively working to reduce the number of households living in substandard housing units. These minimum housing standards were first

(c) The Author(s). 2021 Open Access This article is licensed under a Creative Commons Attribution 4.0 International License, which permits use, sharing, adaptation, distribution and reproduction in any medium or format, as long as you give appropriate credit to the original author(s) and the source, provide a link to the Creative Commons licence, and indicate if changes were made. The images or other third party material in this article are included in the article's Creative Commons licence, unless indicated otherwise in a credit line to the material. If material is not included in the article's Creative Commons licence and your intended use is not permitted by statutory regulation or exceeds the permitted use, you will need to obtain permission directly from the copyright holder. To view a copy of this licence, visit http://creativecommons.org/licenses/by/4.0/ The Creative Commons Public Domain Dedication waiver (http://creativecommons.org/publicdomain/zero/1.0/) applies to the data made available in this article, unless otherwise stated in a credit line to the data. 
introduced in 2000 and later updated in 2011 [3]. As of 2000, about 3.3 million (23.4\%) of Korea's households did not meet the minimum standards [4]. The percentage of households falling beneath the minimum housing standard was significantly reduced to $7.2 \%$ in 2012 and $5.7 \%$ in 2018 [5]. This reduction could be explained by expansion of the public rental housing program [6] and massive scale of housing build up and redevelopment [7]. When examined according to income class, the lower the income level, the higher the ratio of households under the minimum housing standards [8].

The public health community has grown increasingly aware of the importance of the social determinants of health, including housing [9]. Poor housing conditions are associated with a wide range of health conditions, including respiratory infections, asthma, lead poisoning, injuries, and mental health issues [10]. Previous studies show that people living in problematic housing have a greater likelihood of experiencing poor mental health [11-13]. One study used 6 items of poor housing conditions (not enough light; lack of adequate heating; condensation; leaky roof; damp walls or roof etc.;) and 12item General Health Questionnaire to analyzed the association between substandard housing and mental health [14]. Another study used 4 items of substandard housing quality (tapping the cleanliness of the home, the number of rooms in the home, the safety of the building's interior, and safety of the area outside the building) and allostatic load to assessed the association between substandard housing and stress [15].

Similarly, some previous researches suggest that inadequate housing is associated with depression. One study shows that housing instability and disarray are associated with screening positive for depression [16]. Another study indicates that poor quality of housing is associated with depression initially and overtime [17]. However, these studies are restricted to children and females with children. Also, measurement of substandard housing and depression are based on self-report.

Therefore, the study aimed to investigate the potential association between substandard housing and depression using objective measurement tools.

\section{Methods}

\section{Data and population}

We used data from the Korea Welfare Panel Study (KoWePS) conducted by the Korea Institute for Health and Social Affairs and Seoul National University. KoWePS is an annual longitudinal panel survey that began in 2006. It includes 18,856 individuals from 7072 households who were recruited by a two-stage stratified cluster sampling at 2006. Interviews are conducted interviews using a computer assisted personal interviewing (CAPI) technique. This data is suitable for use in low- income policy or poverty studies because about $50 \%$ of the samples are low income earners with a median income of $60 \%$ or less. This study used a sample drawn from waves 11 (2016) to 13 (2018). We used data as cross-sectionally and the outcomes are at waves 11,12 and 13 respectively. Among the population of 15,989 in 2016, we excluded 5585 individuals who provided no answer for survey questionnaires. Thus, the 2016 data included a total of 10,404 individuals.

\section{Measures}

The primary outcome of interest in this study was depression. Depression was measured based on the 11item version of the Center for Epidemiologic Studies Depression Scale (CESD-11). The CESD-11 is a shorter version of the original 20-item instrument and is a wellvalidated self-reported screening tool [18]. The CESD-11 comprises 11 questions; the total score is calculated by adding the scores for all questions and multiplying this value by 11 . Scores range from 0 to 60 , where higher scores indicate increased depressive symptoms.

Substandard housing was our key independent variable. In this study, the operationalization of substandard housing was based on both Korean minimum housing policy and previous research [19]. There are three detailed criteria for the minimum housing standard: the minimum residential area for each household composition and the number of rooms by application, the essential facility standards, and the construction and environmental standards (Supplementary 1). For minimum residential area, the standard criteria were applied to households comprising one to six people, and for households with seven to nine people, it was set by adding square meterage based on the standard. In other words, we cumulatively added $9 \mathrm{~m}^{2}$ - which is the difference between a five-person and a six-person household-to $55 \mathrm{~m}^{2}$, which is the standard for six-person households. The number of rooms was based on one room for one to two people, two rooms for three people, three rooms for four to five people, four rooms for six to eight people, and five rooms for nine people. The minimum housing standards include provisions for essential facilities for daily life, such as access to clean water and sewer facilities, a single standing kitchen, single flush toilet, and single bath facilities. If any of these standards were not met, the location was regarded as substandard housing. Lastly, in relation to construction and environmental standards, KoWePS includes four indicators: structural material should be heat-resistant, fireresistant, provide for heat dissipation, and be moistureproof; provide appropriate soundproofing, ventilation, lighting, and heating facilities; comply with standards of noise, vibration, odor, and air pollution; and not be located in areas where there is a significant risk of natural 
disasters such as tidal waves, floods, mountain accidents, or cliff collapse. In this study, if two or more of the above four indicators were not met, the housing was considered to not meet environmental standards. Collectively, these three detailed criteria-the residential area and number of rooms, essential facilities, and environmental standards-are defined as comprising substandard housing.

Demographic, socioeconomic, and housing variables and health-related factors were included in the study. Demographic variables included gender, household type, age, and region. Socioeconomic variables included education level, marriage status, income level (quartile), and employment status. Housing variables included housing benefit, housing tenure, and housing type. Health-related factors included smoking status, alcohol consumption, perceived health status, and chronic diseases.

\section{Statistical analysis}

We calculated the distribution of the general characteristics at baseline. Analysis of variance (ANOVA) was used to analyze mean CESD-11 scores at time points for categories of experiencing material deprivation. To analyze the effect of substandard housing on depression, we used the generalized estimating equation (GEE) model. The GEE model is known to be efficient and to provide unbiased regression estimates for use in analyzing longitudinal or repeated measures research designs with nonnormal response variables [20]. Statistical analyses were performed using the GENMOD procedure in SAS version 9.4 (SAS Institute, Inc., Cary, NC, USA). The results were considered statistically significant if the $p$-value was less than 0.05 .

\section{Results}

Table 1 presents the general characteristics at baseline (2016). Of the 10,404 participants, $15.6 \%$ male and $15.3 \%$ female live in substandard housing. Participants who live in substandard housing have higher mean scores on the CESD-11 than participants who do not live in substandard housing (live in substandard housing males: 2.88; do not live in substandard housing males: 2.88; live in substandard housing females: 4.32; do not live in substandard housing females: 3.85 ).

Table 2 reports the results of the GEE model analysis of factors associated with depression. Participants living in substandard housing demonstrate higher scores of depression (male: $\beta=0.63$, female: $\beta=0.40$ ) than participants who do not live in substandard housing. Disabled participants have higher depression scores (male: $\beta=$ 0.43 , female: $\beta=0.68$ ) than participants without disabilities. Low-income participants tended to have higher depression scores (male: $\beta=0.84$, female: $\beta=0.88$ ) than people with high incomes. Participants who receive a housing benefit demonstrated higher depression scores (male: $\beta=0.85$, female: $\beta=0.64$ ) than participants who do not receive housing benefit assistance. Moreover, participants who rent their homes showed higher depression scores (male: $\beta=0.36$, female: $\beta=0.35$ ) than those living in owner-occupied homes.

Table 3 outlines the subgroup analysis for the association between substandard housing and depression by covariates. Participants with no disability or disabled household members who live in substandard housing have higher depression scores than non-disabled participants who live in standard housing (male: $\beta=0.62$, female: $\beta=0.41$ ). Moreover, participants who live with disabled household members in substandard housing have higher depression scores than participants who live with disabled household members in standard housing. However, this association was not statistically significant in either men or women. While male participants who's housing tenure is rental and live in substandard housing have higher depression scores than owner-occupation (rental: $\beta=0.59$, owner-occupation: $\beta=0.65$ ), female participants who's housing tenure is owner-occupation and living in substandard housing have higher depression scores than rental (rental: $\beta=0.30$, owner-occupation: $\beta=0.52$ ).

Table 4 shows the results of association between substandard housing and depression based on the three criteria of substandard housing. Male participants who do not meet the minimum requirements for residential area and number of rooms have higher depression scores than those who do not live in substandard housing ( $\beta=$ 0.53). Participants who do not meet construction and environmental standards have higher depression scores than participants who do not live in substandard housing with regard to both men and women (male: $\beta=0.85$, female: $\beta=0.66$ ).

\section{Discussion}

In this study, we examined the potential association between substandard housing and depression. The main findings suggest that living in substandard housing is related to depression. Participants who live without disabled members in their household have association with depression when they live in substandard housing. Among the three criteria for substandard housing, living in a situation that fails to meet construction and environmental standards is most likely to be associated with depression.

Previous studies regarding substandard housing and mental health problems suggest similar associations. One study suggests that damp, moldy, and cold indoor conditions may be associated with anxiety and depression [21]. Another study indicates that living in neighborhoods where noise impedes sleep is associated with 
Table 1 General characteristics of the sample at baseline (2016)

\begin{tabular}{|c|c|c|c|c|c|c|c|c|c|c|c|c|}
\hline \multirow[t]{3}{*}{ Variables } & \multicolumn{12}{|c|}{ CESD-11 } \\
\hline & \multicolumn{5}{|l|}{ Male } & \multirow{2}{*}{$\begin{array}{l}P \\
\text { value }\end{array}$} & \multicolumn{5}{|c|}{ Female } & \multirow{2}{*}{$\begin{array}{l}P \\
\text { value }\end{array}$} \\
\hline & $\mathrm{N}$ & $\%$ & MEANS & \pm & SD & & $\mathrm{N}$ & $\%$ & MEANS & \pm & SD & \\
\hline \multicolumn{13}{|l|}{ Substandard housing } \\
\hline No & 3,940 & 84.4 & 2.88 & \pm & 3.97 & 0.0013 & 4,856 & 84.7 & 3.85 & \pm & 4.46 & 0.0069 \\
\hline Yes & 731 & 15.6 & 3.56 & \pm & 4.39 & & 877 & 15.3 & 4.32 & \pm & 4.69 & \\
\hline \multicolumn{13}{|l|}{ Household type } \\
\hline Without disabled members & 4,189 & 89.7 & 2.82 & \pm & 3.93 & 0.3255 & 5,341 & 93.2 & 3.75 & \pm & 4.40 & $<.0001$ \\
\hline With disabled members & 482 & 10.3 & 4.36 & \pm & 4.71 & & 392 & 6.8 & 6.24 & \pm & 5.13 & \\
\hline \multicolumn{13}{|l|}{ Age (years) } \\
\hline$<30$ & 507 & 10.9 & 2.09 & \pm & 3.56 & 0.0607 & 678 & 11.8 & 2.76 & \pm & 3.94 & $<.0001$ \\
\hline $30-39$ & 692 & 14.8 & 2.20 & \pm & 3.56 & & 756 & 13.2 & 2.47 & \pm & 3.72 & \\
\hline $40-49$ & 957 & 20.5 & 2.42 & \pm & 3.63 & & 945 & 16.5 & 2.63 & \pm & 3.73 & \\
\hline $50-59$ & 794 & 17.0 & 2.81 & \pm & 3.97 & & 897 & 15.6 & 3.60 & \pm & 4.26 & \\
\hline $60-69$ & 680 & 14.6 & 3.17 & \pm & 3.99 & & 933 & 16.3 & 4.34 & \pm & 4.51 & \\
\hline$\geq 70$ & 1,041 & 22.3 & 4.46 & \pm & 4.58 & & 1,524 & 26.6 & 5.88 & \pm & 4.91 & \\
\hline \multicolumn{13}{|l|}{ Region } \\
\hline Metropolitan & 1,977 & 42.3 & 2.83 & \pm & 3.99 & 0.1666 & 2,444 & 42.6 & 3.64 & \pm & 4.50 & 0.0235 \\
\hline Rural & 2,694 & 57.7 & 3.09 & \pm & 4.08 & & 3,289 & 57.4 & 4.12 & \pm & 4.50 & \\
\hline \multicolumn{13}{|l|}{ Education level } \\
\hline Middle school or under & 1,297 & 27.8 & 4.38 & \pm & 4.57 & $<.0001$ & 2,600 & 45.4 & 5.26 & \pm & 4.82 & 0.0004 \\
\hline High school & 1,543 & 33.0 & 2.69 & \pm & 3.80 & & 1,468 & 25.6 & 3.04 & \pm & 4.05 & \\
\hline College or above & 1,831 & 39.2 & 2.24 & \pm & 3.57 & & 1,665 & 29.0 & 2.60 & \pm & 3.72 & \\
\hline \multicolumn{13}{|l|}{ Marriage status } \\
\hline Living w/ spouse & 4,480 & 95.9 & 3.03 & \pm & 4.07 & 0.0817 & 5,632 & 98.2 & 3.95 & \pm & 4.51 & 0.1511 \\
\hline Living w/o spouse & 191 & 4.1 & 1.80 & \pm & 3.24 & & 101 & 1.8 & 2.16 & \pm & 3.42 & \\
\hline \multicolumn{13}{|l|}{ Income level } \\
\hline Low & 947 & 20.3 & 4.68 & \pm & 4.70 & 0.0003 & 1,664 & 29.0 & 5.69 & \pm & 4.92 & $<.0001$ \\
\hline Lower middle & 1,255 & 26.9 & 3.23 & \pm & 4.06 & & 1,416 & 24.7 & 3.80 & \pm & 4.40 & \\
\hline Upper middle & 1,253 & 26.8 & 2.35 & \pm & 3.63 & & 1,318 & 23.0 & 3.07 & \pm & 4.06 & \\
\hline High & 1,216 & 26.0 & 2.06 & \pm & 3.39 & & 1,335 & 23.3 & 2.67 & \pm & 3.71 & \\
\hline \multicolumn{13}{|l|}{ Employment type } \\
\hline Permanent employee & 2,503 & 53.6 & 2.49 & \pm & 3.64 & 0.0129 & 1,290 & 22.5 & 3.39 & \pm & 4.27 & 0.2980 \\
\hline Temporary employee & 545 & 11.7 & 2.65 & \pm & 3.80 & & 787 & 13.7 & 3.11 & \pm & 4.12 & \\
\hline Daily hired employee & 359 & 7.7 & 3.59 & \pm & 4.19 & & 844 & 14.7 & 4.18 & \pm & 4.34 & \\
\hline Nonemployee & 1,264 & 27.1 & 3.93 & \pm & 4.63 & & 2,812 & 49.0 & 4.31 & \pm & 4.70 & \\
\hline \multicolumn{13}{|l|}{ Housing benefit } \\
\hline Yes & 4,462 & 95.5 & 2.86 & \pm & 3.95 & $<.0001$ & 5,420 & 94.5 & 3.83 & \pm & 4.45 & 0.5875 \\
\hline No & 209 & 4.5 & 5.58 & \pm & 5.09 & & 313 & 5.5 & 5.42 & \pm & 5.17 & \\
\hline \multicolumn{13}{|l|}{ Housing Tenure } \\
\hline Owner-occupation & 3,126 & 66.9 & 2.82 & \pm & 3.93 & 0.0099 & 3,617 & 63.1 & 3.69 & \pm & 4.36 & $<.0001$ \\
\hline Rental & 1,545 & 33.1 & 3.31 & \pm & 4.24 & & 2,116 & 36.9 & 4.30 & \pm & 4.72 & \\
\hline \multicolumn{13}{|l|}{ Housing Type } \\
\hline Detached dwelling & 1,168 & 25.0 & 3.62 & \pm & 4.30 & 0.4465 & 1,541 & 26.9 & 4.74 & \pm & 4.67 & 0.5302 \\
\hline Multi-family house & 3,321 & 71.1 & 2.77 & \pm & 3.94 & & 3,966 & 69.2 & 3.61 & \pm & 4.40 & \\
\hline
\end{tabular}


Table 1 General characteristics of the sample at baseline (2016) (Continued)

\begin{tabular}{|c|c|c|c|c|c|c|c|c|c|c|c|c|}
\hline \multirow[t]{3}{*}{ Variables } & \multicolumn{12}{|c|}{ CESD-11 } \\
\hline & \multicolumn{5}{|l|}{ Male } & \multirow{2}{*}{$\begin{array}{l}P \\
\text { value }\end{array}$} & \multicolumn{5}{|c|}{ Female } & \multirow{2}{*}{$\begin{array}{l}P \\
\text { value }\end{array}$} \\
\hline & $\mathrm{N}$ & $\%$ & MEANS & \pm & SD & & $\mathrm{N}$ & $\%$ & MEANS & \pm & SD & \\
\hline Commercial building & 182 & 3.9 & 2.70 & \pm & 3.79 & & 226 & 3.9 & 3.71 & \pm & 4.50 & \\
\hline \multicolumn{13}{|l|}{ Smoking status } \\
\hline Current smoker & 1,639 & 35.1 & 2.96 & \pm & 4.04 & 0.0420 & 120 & 2.1 & 5.91 & \pm & 5.29 & 0.0010 \\
\hline Non-smoker & 3,032 & 64.9 & 3.00 & \pm & 4.05 & & 5,613 & 97.9 & 3.88 & \pm & 4.47 & \\
\hline \multicolumn{13}{|l|}{ Alcohol consumption } \\
\hline Yes & 1,519 & 32.5 & 3.37 & \pm & 4.28 & 0.0623 & 3,885 & 67.8 & 4.16 & \pm & 4.60 & 0.0015 \\
\hline No & 3,152 & 67.5 & 2.79 & \pm & 3.91 & & 1,848 & 32.2 & 3.40 & \pm & 4.25 & \\
\hline \multicolumn{13}{|l|}{ Percieved health status } \\
\hline Healthy & 4,093 & 87.6 & 2.67 & \pm & 3.82 & $<.0001$ & 4,785 & 83.5 & 3.49 & \pm & 4.27 & $<.0001$ \\
\hline Unhealthy & 578 & 12.4 & 5.21 & \pm & 4.83 & & 948 & 16.5 & 6.09 & \pm & 5.01 & \\
\hline \multicolumn{13}{|l|}{ Chronic diseases } \\
\hline Yes & 2,406 & 51.5 & 2.25 & \pm & 3.48 & $<.0001$ & 2,577 & 45.0 & 2.78 & \pm & 3.91 & 0.0042 \\
\hline No & 2,265 & 48.5 & 3.76 & \pm & 4.43 & & 3,156 & 55.0 & 4.85 & \pm & 4.73 & \\
\hline Total & 4,671 & 100.0 & 2.99 & \pm & 4.05 & & 5,733 & 100.0 & 3.92 & \pm & 4.50 & \\
\hline
\end{tabular}

poor mental health [22]. Similarly, in our study indicates that participants who live in house that does not meet construction and environmental standards such as noise, vibration, odor, air pollution, ventilation have higher depression score. Further, living in substandard housing may be related to behavioral problems among children [23]. Similar results were found in this study that living in substandard housing that does not meet the minimum residential area and number of rooms are associated with mental health problem. Although the targeted population were different. Pragmatic concerns and fear may explain these results; living in substandard housing is a psychosocial stressor that can lead to mental health problems [10]. There is strong accumulated evidence that episodic stressors play a causal role in many instances of depression [24].

A key finding of this study was that the results of our subgroup analysis of substandard housing in association with depression stratified by household type. Regardless of whether the participant or a member of their household was disabled, if that participant lives in substandard housing, they are likely to have a higher depression score than a participant living in standard housing. However, the results were only statistically significant in participants without disabled household members. This result may be explained by the cash benefits offered by a disability pension, which is an income support for people with severe disabilities [25]. Moreover, in South Korea, disabled people benefit from the National Basic Livelihood Security System (NBLSS). The NBLSS is an integrated benefit system comprising four areas: Livelihood Benefit, Medical Benefit, Housing Benefit, and Education
Benefit [26]. The housing benefit includes a discount to one's electricity and heating bills. As economic burdens elevate the risk of depression [27], financial support may act as a buffer, lowering the risk of depression.

Another key finding was that among the three minimum housing standards criteria, construction and environmental standards are most likely to be associated with depression. Construction and Environmental standards include noise, vibration, odor, air pollution, ventilation, and so on. It is well known that prolonged exposure to damp, mold, noise, and odor in one's living environment are associated with mental health issues [21, 22, 28, 29]. However, an interesting result of this study was that essential facilities, including water and sewage, a single standing kitchen, single flush toilet, and single bath facilities, do not appear to be associated with depression. One possible explanation for this result is that most participants may meet the essential facility criteria; however, further research is needed in this area.

Evaluations of housing renewal programs for people living in poor conditions, as well as research regarding early educational interventions, show that improving social conditions can contribute to improved mental health status [30]. Korea officially works to support people living in substandard housing via several programs [4]. The Public Rental Housing Programs comprise the main low-income housing policies in Korea. Those enrolled in these programs receive favorable treatments in terms of land acquisition, long-term financing below market rates, and tax deductions and exemptions. To assist with housing acquisition and expenses, there are two types of Demand-Side Programs: the deposit loan program and 
Table 2 Results of the generalized estimating equation analysis of factors associated with depression

\begin{tabular}{|c|c|c|c|c|c|c|}
\hline \multirow[t]{3}{*}{ Variables } & \multicolumn{6}{|c|}{ CESD-11 } \\
\hline & \multicolumn{3}{|c|}{ Male } & \multicolumn{3}{|c|}{ Female } \\
\hline & $\bar{B}$ & S. E & $P$ value & $\bar{B}$ & S. E & $P$ value \\
\hline \multicolumn{7}{|l|}{ Substandard housing } \\
\hline No & Ref. & & & Ref. & & \\
\hline Yes & 0.63 & 0.11 & $<.0001$ & 0.40 & 0.11 & 0.0002 \\
\hline \multicolumn{7}{|l|}{ Household type } \\
\hline without disabled members & Ref. & & & Ref. & & \\
\hline with disabled members & 0.43 & 0.15 & 0.0045 & 0.68 & 0.18 & 0.0001 \\
\hline \multicolumn{7}{|l|}{ Age (years) } \\
\hline$<30$ & Ref. & & & Ref. & & \\
\hline $30-39$ & 0.26 & 0.15 & 0.0824 & -0.16 & 0.14 & 0.2544 \\
\hline $40-49$ & 0.35 & 0.15 & 0.0169 & -0.41 & 0.14 & 0.0040 \\
\hline $50-59$ & 0.44 & 0.16 & 0.0064 & 0.07 & 0.17 & 0.6772 \\
\hline $60-69$ & 0.20 & 0.17 & 0.2331 & 0.18 & 0.19 & 0.3465 \\
\hline$\geq 70$ & 0.81 & 0.19 & $<.0001$ & 1.03 & 0.21 & $<.0001$ \\
\hline
\end{tabular}

Region

Metropolitan Ref.

Rural

Education level

Middle school or under

High school

College or above

\section{Marriage status}

Living $w /$ spouse
Living $w / 0$ spouse

\section{Income level}

Low

Lower middle

Upper middle

High

\section{Employment type}

Permanent employee

Temporary employee

Daily hired employee

Nonemployee

Housing benefit

Yes

No

Housing Tenure

Owner-occupation

Rental

Housing Type

Detached dwelling

Multi-family house
0.14

0.55

0.14

Ref.

Ref.

$-0.23$

0.84

0.24

0.08

Ref.

Ref.

0.14

0.46

0.47

0.85

Ref.

Ref.

0.36

Ref.

$-0.06$
0.12

0.15

0.11

0.23

0.0002

0.2288

0.0024

$<.0001$

$<.0001$

0.09

0.5786
Ref.

0.24

0.09

0.0047

0.79

0.16

$<.0001$

0.19

0.11

0.0831

Ref.

Ref.

$-0.61$

0.23

0.0071

0.88

0.32

0.14

$<.0001$

0.15

0.11

0.0024

Ref.

0.10

0.1247

Ref.

$-0.19$

0.12

0.1080

$-0.31$

0.13

0.0146

$-0.08$

0.10

0.4283

0.64

0.19

0.0009

Ref.

Ref.

0.35

0.09

$<.0001$

Ref.

0.15

0.11

0.1484 
Table 2 Results of the generalized estimating equation analysis of factors associated with depression (Continued)

\begin{tabular}{|c|c|c|c|c|c|c|}
\hline \multirow[t]{3}{*}{ Variables } & \multicolumn{6}{|c|}{ CESD-11 } \\
\hline & \multicolumn{3}{|l|}{ Male } & \multicolumn{3}{|c|}{ Female } \\
\hline & $\bar{B}$ & S. E & $P$ value & $\bar{B}$ & S. E & $P$ value \\
\hline Commercial building & -0.17 & 0.19 & 0.3668 & -0.03 & 0.20 & 0.8800 \\
\hline \multicolumn{7}{|l|}{ Smoking status } \\
\hline Current smoker & 0.37 & 0.08 & $<.0001$ & 1.23 & 0.30 & $<.0001$ \\
\hline Non-smoker & Ref. & & & Ref. & & \\
\hline \multicolumn{7}{|l|}{ Alcohol consumption } \\
\hline Yes & 0.11 & 0.08 & 0.1854 & 0.24 & 0.08 & 0.0026 \\
\hline No & Ref. & & & Ref. & & \\
\hline \multicolumn{7}{|l|}{ Percieved health status } \\
\hline Healthy & Ref. & & & Ref. & & \\
\hline Unhealthy & 1.19 & 0.13 & $<.0001$ & 1.05 & 0.11 & $<.0001$ \\
\hline \multicolumn{7}{|l|}{ Chronic diseases } \\
\hline Yes & 0.53 & 0.08 & $<.0001$ & 0.46 & 0.09 & $<.0001$ \\
\hline No & Ref. & & & Ref. & & \\
\hline
\end{tabular}

Table 3 Subgroup analysis of substandard housing association to depression stratified by covariates

\begin{tabular}{|c|c|c|c|c|}
\hline \multirow[t]{3}{*}{ Variables } & \multicolumn{4}{|c|}{ CESD-11 } \\
\hline & \multirow{2}{*}{$\begin{array}{l}\text { No } \\
\text { B }\end{array}$} & \multicolumn{3}{|l|}{ Yes } \\
\hline & & $B$ & S. E & $P$ value \\
\hline \multicolumn{5}{|l|}{ Male } \\
\hline \multicolumn{5}{|l|}{ Household type } \\
\hline Without disabled members & Ref. & 0.62 & 0.12 & $<.0001$ \\
\hline With disabled members & Ref. & 0.67 & 0.38 & 0.0784 \\
\hline \multicolumn{5}{|l|}{ Housing Tenure } \\
\hline Owner-occupation & Ref. & 0.59 & 0.17 & 0.0005 \\
\hline Rental & Ref. & 0.65 & 0.15 & $<.0001$ \\
\hline \multicolumn{5}{|l|}{ Housing Type } \\
\hline Detached dwelling & Ref. & 0.88 & 0.23 & 0.0002 \\
\hline Multi-family house & Ref. & 0.56 & 0.14 & $<.0001$ \\
\hline Commercial building & Ref. & 0.22 & 0.41 & 0.6011 \\
\hline \multicolumn{5}{|l|}{ Female } \\
\hline \multicolumn{5}{|l|}{ Household type } \\
\hline Without disabled members & Ref. & 0.41 & 0.11 & 0.0002 \\
\hline With disabled members & Ref. & 0.23 & 0.43 & 0.5849 \\
\hline \multicolumn{5}{|l|}{ Housing Tenure } \\
\hline Owner-occupation & Ref. & 0.52 & 0.16 & 0.0015 \\
\hline Rental & Ref. & 0.30 & 0.15 & 0.0368 \\
\hline \multicolumn{5}{|l|}{ Housing Type } \\
\hline Detached dwelling & Ref. & 0.35 & 0.21 & 0.0924 \\
\hline Multi-family house & Ref. & 0.44 & 0.13 & 0.0009 \\
\hline Commercial building & Ref. & 0.58 & 0.39 & 0.1358 \\
\hline
\end{tabular}

the housing benefits program. The deposit loan program lends some portion of the required deposit at a belowmarket interest rate, whereas the housing benefits program offers a cash subsidy support based on household size.

Despite these efforts, a UN report [31] revealed that in Korea, the number of people who live in substandard housing is increasing. This poses a serious threat to wellbeing: those who live in substandard housing are easily exposed to greater risks of fire and crime as well as the risks inherent to the poor living environment. The report also indicates that women, young people, the elderly, migrant workers, people with disabilities, and sexual minorities living in substandard housing are more often subject to discrimination and social exclusion from residential welfare.

This study has several limitations. First, measures of substandard housing are based on self-report; therefore, under- or overestimation of behaviors and conditions may have affected the accuracy of reporting among participants. Second, we could not include a factor related to the contextual appropriateness of participants' housing cost burden, such as ability to pay their rent or mortgage, or being able to buy a home. However, we were able to include some housing-related variables such as housing benefit, housing tenure, and housing type. Third, because personality characteristics and medical history are likely to be associated with depression, our inability to include these in our statistical models may have resulted in exaggerating the associations under investigation.

Despite these limitations, this study has several strengths. First, this study worked to identify 
Table 4 Association between substandard housing and depression based on three criteria of substandard housing

\begin{tabular}{|c|c|c|c|c|c|c|}
\hline \multirow[t]{3}{*}{ Variables } & \multicolumn{6}{|c|}{ CESD-11 } \\
\hline & \multicolumn{3}{|c|}{ Male } & \multicolumn{3}{|c|}{ Female } \\
\hline & $B$ & S.E & $P$ value & $B$ & S.E & $P$ value \\
\hline \multicolumn{7}{|l|}{ Substandard housing } \\
\hline No & Ref. & & & Ref. & & \\
\hline \multicolumn{7}{|l|}{ Yes } \\
\hline Minimum residential area and number of rooms & 0.53 & 0.13 & $<.0001$ & 0.22 & 0.12 & 0.0712 \\
\hline Essential facility & 0.52 & 0.33 & 0.1156 & 0.27 & 0.31 & 0.3724 \\
\hline Construction and environmental standards & 0.85 & 0.19 & $<.0001$ & 0.66 & 0.19 & 0.0006 \\
\hline
\end{tabular}

associations by using three-year longitudinal data relying on a national sample; thus, the results may be generalized to the Korean population as a whole with some confidence. The study expands our knowledge of the effects of substandard housing outside its most common context. Most previous studies in this area have targeted European populations, rarely studying the effects of substandard housing in Asian populations. Thus, this study contributes to the literature by using minimum housing standards as a measure of substandard housing and its potential association to depression among South Koreans.

\section{Conclusion}

In conclusion, this study identified an association between substandard housing and depression by gender, and the results were significant. We found that among the three criteria for substandard housing, construction and environmental standards are most likely associated with depression. Despite the Korean government's efforts to provide housing assistance of various types and to improve standards of living throughout the nation, some portion of the population still lives in substandard housing. Based on this study, we should consider means of improving housing environmental factors to mitigate the psychosocial stresses of living in substandard housing, thus helping to combat depression and improve mental health among this population.

\section{Supplementary Information}

The online version contains supplementary material available at https://doi. org/10.1186/s12888-020-03011-2.

\section{Additional file 1.}

\section{Abbreviations}

OR: Odds ratio; Cl: Confidence interval; KoWePS: Korea Welfare Panel Study; CESD-11: 11-item version of the Center for Epidemiologic Studies Depression Scale; ANOVA: Analysis of variance; GEE: Generalized estimating equation; NBLSS: National Basic Livelihood Security System

\begin{abstract}
Acknowledgements
All persons who have made substantial contributions to the work reported in the manuscript (e.g., technical help, writing and editing assistance, general support), but who do not meet the criteria for authorship, are named in the Acknowledgements and have given us their written permission to be named. If we have not included an acknowledgement, then that indicates that we have not received substantial contributions from non-authors.
\end{abstract}

\section{Authors' contributions}

SK designed this study, performed statistical analysis, drafted and completed the manuscript. SK, WJ, BNJ contributed to the concept and design of the study and revised the manuscript. SIJ provided statistical expertise and interpretation of data. ECP and SIJ conceived, designed and directed this study. All authors read and approved the final manuscript.

\section{Funding}

This study was supported by a faculty research grant by Yonsei University College of Medicine (6-2018-0174 and 6-2017-0157). The funding body was not involved in the design of the study, the collection, analysis, and interpretation of data and in writing the manuscript.

\section{Availability of data and materials}

https://www.koweps.re.kr:442/main.do;jsessionid=64D4F10703F4D419DF13 D77E6104A44B

\section{Ethics approval and consent to participate}

The KoWePS survey data are openly published, so ethical approval was not applicable for this study. This study did not collect inform consent from the participants, because their information was fully anonymized prior to analysis.

\section{Consent for publication}

Not applicable.

\section{Competing interests}

None declared.

\section{Author details}

${ }^{1}$ Department of Public Health, Graduate School, Yonsei University, Seoul, Republic of Korea. ${ }^{2}$ Institute of Health Services Research, Yonsei University, Seoul, Republic of Korea. ${ }^{3}$ Department of Preventive Medicine \& Institute of Health Services Research, Yonsei University College of Medicine, 50 Yonsei-ro, Seodaemun-gu, Seoul 03722, Republic of Korea.

Received: 14 June 2020 Accepted: 11 December 2020

Published online: 07 January 2021

\section{References}

1. HCR U. Official Records of the General Assembly, Forty-third Session, Supplement No. 8, addendum (A/43/8/Add.1). 1989.

2. CESCR U. General comment no. 4: the right to adequate housing (art. 11 (1) of the covenant). 1991

3. Yoshino N, Helble M. The housing challenge in emerging Asia: options and solutions: Asian Development Bank Institute; 2016. 
4. Chung E-C. Low income housing policies in Korea: evaluations and suggestions, International Conference of Korea Development Institute, Residential Welfare and Housing Policies: The Experience and Future of Korea; 2005. p. 2-3.

5. KOSIS. Percentage of households under the minimum housing standard. Available at: http://www.index.go.kr/unify/idx-info.do?idxCd=8014 Accessed 10 May 2020.

6. Won J, Lee J-S. Impact of residential environments on social capital and health outcomes among public rental housing residents in Seoul, South Korea. Landscape Urban Plan. 2020;203:103882.

7. Yoon $\mathrm{H}$. Transforming the economic value of hillside housing - a case study of Seoul, South Korea. Urban Forestry Urban Green. 2017;24:35-44.

8. Hyun J, Lee Y, Ahn S. A analysis on the previous Research Trend of'Minimum housing Standard'. Korean Instit Interior Design J. 2017;26:3-11.

9. Marmot M, Wilkinson R. Social determinants of health: OUP Oxford; 2005.

10. Krieger J, Higgins DL. Housing and health: time again for public health action. Am J Public Health. 2002;92:758-68.

11. Hopton JL, Hunt SM. Housing conditions and mental health in a disadvantaged area in Scotland. J Epidemiol Comm Health. 1996;50:56-61.

12. Pevalin DJ, Taylor MP, Todd J. The dynamics of unhealthy housing in the UK: a panel data analysis. Hous Stud. 2008;23:679-95.

13. Aro $S$, Hänninen V. Life events or life processes as determinants of mental strain? A 5-year follow-up study. Soc Sci Med. 1984;18:1037-44.

14. Pevalin DJ, Reeves A, Baker E, Bentley R. The impact of persistent poor housing conditions on mental health: a longitudinal population-based study. Prev Med. 2017;105:304-10.

15. Blair C, Raver C, Granger D, Mills-Koonce R, Hibel L. Allostasis and allostatic load in the context of poverty in early childhood. Dev Psychopathol. 2011 23:845.

16. Suglia SF, Duarte CS, Sandel MT. Housing quality, housing instability, and maternal mental health. J Urban Health. 2011;88:1105-16.

17. Rollings KA, Wells NM, Evans GW, Bednarz A, Yang Y. Housing and neighborhood physical quality: Children's mental health and motivation. J Environ Psychol. 2017;50:17-23.

18. Kohout FJ, Berkman LF, Evans DA, Cornoni-Huntley JJJoa, health. Two shorter forms of the CES-D depression symptoms index. J Aging Health. 1993:5:179-93.

19. Park J, Heo Y, Oh U, Yoon S. Changes in physical and mental health as a function of substandard housing conditions and unaffordable housing. Korean J Soc Welfare. 2015:67:137-59.

20. Ballinger GA. Using generalized estimating equations for longitudinal data analysis. Organ Res Methods. 2004;7:127-50.

21. Hyndman S. Housing dampness and health amongst British Bengalis in East London. Soc Sci Med. 1990;30:131-41.

22. Novoa AM, Ward J, Malmusi D, Díaz F, Darnell M, Trilla C, et al. How substandard dwellings and housing affordability problems are associated with poor health in a vulnerable population during the economic recession of the late 2000s. Int J Equity Health. 2015;14:120.

23. Zima BT, Wells KB, Freeman HE. Emotional and behavioral problems and severe academic delays among sheltered homeless children in Los Angeles County. Am J Public Health. 1994;84:260-4.

24. Hammen C. Stress and depression. Ann Rev Clin Psychol. 2005;1:293-319.

25. MOHW. Disability Pension. Available at: http://www.bokjiro.go.kr/pension/ p03.jsp (11 Accessed May 2020].

26. Nam J, Park H. The 2015 welfare reform of the National Basic Livelihood Security System in South Korea: effects on economic outcomes. Int J Soc Welf. 2018;11:3-27.

27. Simon GE. Social and economic burden of mood disorders. Biol Psychiatry. 2003;54:208-15.

28. Lim Y-H, Kim H, Kim JH, Bae S, Park HY, Hong Y-C. Air pollution and symptoms of depression in elderly adults. Environ Health Perspect. 2012; 120:1023-8.

29. Pentzek M, Grass-Kapanke B, Ihl R. Odor identification in Alzheimer's disease and depression. Aging Clin Exp Res. 2007;19:255-8.

30. Harvey TB. John housing renewal and mental health: a case study. J Ment Health. 2001;10:571-83.

31. UN. Report of the Special Rapporteur on adequate housing as a component of the right to an adequate standard of living, and on the right to nondiscrimination in this context, Human Rights Council, A/HRC/40/61/Add.1. 2019

\section{Publisher's Note}

Springer Nature remains neutral with regard to jurisdictional claims in published maps and institutional affiliations.
Ready to submit your research? Choose BMC and benefit from:

- fast, convenient online submission

- thorough peer review by experienced researchers in your field

- rapid publication on acceptance

- support for research data, including large and complex data types

- gold Open Access which fosters wider collaboration and increased citations

- maximum visibility for your research: over $100 \mathrm{M}$ website views per year

At BMC, research is always in progress.

Learn more biomedcentral.com/submissions 